\title{
Comparative Profitability of Melon and Watermelon Production in South Konawe District of Southeast Sulawesi
}

\author{
HAJI SAEDIMAN ${ }^{*}$, LA ODE ALWI ${ }^{1}$, ILMA SARIMUSTAQIYMA RIANSE ${ }^{1}$, \\ SITTI AIDA ADHA TARIDALA ${ }^{1}$, SALAHUDDIN SALAHUDDIN ${ }^{2}$, \\ YUSNA INDARSYIH ${ }^{1}$, RIZKI WIDYA ASTUTI ${ }^{3}$ \\ ${ }^{1}$ Department of Agribusiness, Faculty of Agriculture, \\ Halu Oleo University, Kampus Bumi Tridarma Anduonohu, Kendari 93232 \\ INDONESIA \\ ${ }^{2}$ Department of Agricultural Extension, Faculty of Agriculture, \\ Halu Oleo University, Kampus Bumi Tridarma Anduonohu, Kendari 93232 \\ INDONESIA \\ ${ }^{3}$ Independent researcher, Ranomeeto, Kabupaten Konawe Selatan, Sulawesi Tenggara
}

INDONESIA

\begin{abstract}
Melon and watermelon are two high-value crops that have been commercially cultivated recently in Southeast Sulawesi. The objective of the study was to examine and compare the cost and returns of melon and watermelon production. The study was conducted in Abenggi village in South Konawe district of Southeast Sulawesi. Twenty melon farmers and 20 watermelon farmers were selected as respondents. Data collection was done using a questionnaire-based interview method. Data and information were analyzed using cost and returns analysis and independent sample t-test. Results of the study revealed that both melon and watermelon production were profitable as indicated by their revenue-cost ratio being higher than 1 . Due to small size of farming, difference in net returns per farm from melon and watermelon was not statistically significant. Per hectare net returns from melon farming were statistically significantly higher than that of watermelon farming. Net returns from either melon or watermelon farming were higher than that of many other crops in the province. Farmers should continue to focus on the cultivation of the crops as they can increase their income and promote rural economy. The local government should assist the development of the two crops by ensuring availability of farm inputs and improving provision of weather forecast results to the farmers.
\end{abstract}

Key-Words: comparative, melon, production, profitability, Sulawesi, watermelon

Received: June 20, 2020. Revised: November 11, 2020. Accepted: November 18, 2020.

Published: November 23, 2020.

\section{Introduction}

Melon (Cucumis melo) and watermelon (Citrullus lanatus) are two widely cultivated crops in the world [1]. Both crops belong to Cucurbitaceae family and are grown in tropical, subtropical and temperate region [2]. Global production of melon in 2017 accounts for 31.9 million tons with the cultivated area reaching 1.22 million ha [3]. The most important share in production belongs to China (53.7 percent), Turkey (5.7 percent), India (3.2 percent), and USA ( 2.4 percent) [3]. With regard to watermelon, in 2017 the cultivated area is 3.48 million ha with the total production of 118.4 million tons [3]. The global consumption of watermelon is the highest among cucurbit.

Fruits are nutritionally important to human as they provide the much needed energy, vitamin, minerals and fiber. In Indonesia, the overall consumption of fruits is lower than the recommended level. Saediman et al. [4] and Zani et $a l$. [5] reported that the low-income households still give more priority to quantitative adequacy of foods than to its nutritional content and quality. Based on Dietary Diversity Score, Indonesians tend to eat more cereals and fewer tubers and roots, meat, vegetables, and fruits [6]. According to Anwar and Hardinsyah [7], food consumption in Indonesia is 
characterized by (1) the lack of quality, being less diversified, and the dominance of carbohydratesource food, and (2) low consumption level of vegetables, fruits, and beans. At the same time, some fruit crops play a significant role in agricultural production system and rural residents' well-being. Therefore, development of fruit crops and their increased consumption can help improve food and nutrition security and foster rural development.

Melon and watermelon are the two most important seasonal fruit crops in Indonesia in terms of the cultivated area and production. Their production fluctuates but shows an increasing trend due to greater appreciation of their nutritional and economic value. In 2009, the cultivated area for melon is 4,859 ha and the production is 85,861 tons, which increased to 5,879 ha and 92,435 tons in 2017 for the cultivated area and the production, respectively $[8,9]$. Likewise, in 2009, the cultivated area for watermelon is 34,219 ha and production is 474,327 tons, which increased to 32,558 ha and 499,469 tons in 2017 for the cultivated area and production, respectively $[8,9]$. The three largest melon producing provinces are East Java, Central Java, and Yogyakarta, which together contribute 83.4 percent of the total national production. Concerning watermelon, East Java, Central Java, and North Sumatera are three provinces that contribute to half of the total national production.

Despite their nutritional and commercial value, and suitability of soil structure and climatic condition, production of melon and watermelon is still very low in Southeast Sulawesi. Melon and watermelon are relatively new crops in the province, so that they are not yet included in the priority crops [10] and are still produced by farmers on a smallscale. In 2014, the cultivated area for melon is only 10 ha with production accounting for 44 tons, which increased to 33 ha with production accounting for 1,986 tons in 2018 [11]. Likewise, in 2014, the cultivated area for watermelon is 271 ha with production accounting for 1,266 , which increased to 244 ha and 9,366 tons in 2018, respectively [10]. Less cultivation in the province might be due to the lack of knowledge and skills in farming practices, lack of storage facilities, and lack of knowledge of markets. Farmers might not fully understand the customer demand, seasonal price fluctuation, and the cost and returns relationship of the two crops. Therefore, melon and watermelon are only grown in areas where farmers have knowledge and skills as well as high entrepreneurship, such as in transmigration areas [12].
Given the nutritional and commercial importance of melon and watermelon and their high potential for further expansion in the province, the present research was designed to make the economic analysis of their production in the study area. Information on the production cost and returns from the two crops will be useful in the efforts to enhance their productivity, profitability, and sustainability of their production in the province. The study results can also be used as a reference for potential producers and investors to make investment decisions on melon and watermelon production.

\section{Materials and Methods}

The study was undertaken from July to August 2019 in Abenggi village, Landono sub-district, South Konawe district. South Konawe is situated between the latitude $3^{\circ} 59^{\prime}$ and $4^{\circ} 32^{\prime}$ South, and the longitude $121^{\circ} 58^{\prime}$ and $123^{\circ} 16^{\prime}$ East. The village is situated 43 kilometers from Kendari, the provincial capital. The village population was 634 consisting of 194 households. Villagers working in agriculture accounted for 108 persons. The village has an area of $3.5 \mathrm{~km}^{2}$ with an average annual rainfall of $2,726.3$ $\mathrm{mm}$. Temperatures range from $23^{\circ} \mathrm{C}$ to $32^{\circ} \mathrm{C}$ throughout the year.

Farmers in the study village grew various horticultural crops, such as melon, watermelon, chilli, tomato, and key lime. Many farmers did not permanently grow a particular crop as they might switch from one crop to another depending on some factors such as weather, price, resources, and possible risks. We selected farmers who were relatively consistent to grow melon and watermelon as respondents, namely, 20 melon farmers and 20 watermelon farmers. Data were collected through interviews based on the questionnaires. Cost and returns analysis [13-15] and independent sample ttest were employed to analyze data and information. The data of net returns from the two crops were compared by SPSS 16 . For the independent sample $t$ test, $\alpha$ was set at 0.05 and $\rho$ less than significance level 0.05 being considered as statistically significant. The null hypothesis is that the population means of the net returns from the two groups are equal $\left(\mathrm{H}_{0}: \mu_{1}=\mu_{2}\right)$, and the alternative hypothesis is that the population means are not equal $\left(H_{1}: \mu_{1} \neq \mu_{2}\right)$.

Melon and watermelon are annual crops planted twice or three times a year depending on the weather condition. In this study, comparison of the net returns between the two crops was calculated for one year with the assumption that they are planted 
twice in a year. Unpaid family labor costs were not included in the cost calculation. Interest on variable cost which reflected the opportunity cost of capital invested for production [16] was not calculated.

\section{Results and Discussion}

\subsection{Socioeconomic characteristics of respondents}

On average, the age of melon farmers was 51 years, and that of watermelon farmers was 49 years. This average age implies that the majority of respondents were in their productive ages, and watermelon farmers were younger than melon farmers. Length of education for the two groups of respondents was the same, namely nine years, or until they completed junior high school. The average number of household members was also similar, namely, four persons. On average, the farm size for melon farmers was 0.36 ha and that of watermelon farmers was 0.43 ha. The average length of farming experience for melon farmers was 5.4 years on average, while that of watermelon farmers was 5.1 years. This length of farming experience showed that melon and watermelon growing were the newly introduced profession in the study area and were adopted at the same time. Farmers previously grew low-land rice and then shifted to melon and watermelon due to, among others, a higher risk of failure with rice farming [17].

\subsection{Economic returns of melon}

Table 1 shows the cost and returns of melon production among the respondents. The total production cost per farm was Rp25,203,550, which consisted of variable cost and fixed cost. The share of total variable cost in the total cost was 98.87 percent. The smallest variable cost was for paid labor (1.79 percent), and the highest was for seed (31.07 percent). The cost of seed and mulching sheet was 62.14 percent of the total cost, which constituted the highest cost among all components in the variable costs. Unlike rice farming where labor cost formed the highest component in the variable cost, the proportion of labor cost in the total variable cost was only 1.79 . This is because respondents use family labors in most of farming operations. Hired labors were used in planting and harvesting, including tractors during land preparation. Total fixed cost was Rp284,300 or 1.13 percent of the total cost. Fixed costs consisted of depreciation and tax. Depreciation consisted of depreciation for tools and equipment.

Some characteristics of farming operation and management determine the amount of cost of melon cultivation. Farmers plant melon on their land so there is no need to pay rental value of land. The buyers come to the growing sites during harvest time so farmers did not spend cost for transportation to the market. Paid human labor was used for planting and harvesting, and tractor for land preparation. Farmers used their own capital to finance farming operations. Family labors were used predominantly but were not included in the cost calculation.

Table 1. Cost and returns of melon farming

\begin{tabular}{|l|r|r|}
\hline \multicolumn{1}{|c|}{ Items } & \multicolumn{1}{c|}{$\begin{array}{c}\text { Value } \\
\text { (Rp/year) }\end{array}$} & \multicolumn{1}{c|}{$\%$} \\
\hline A. Variable cost & & \\
Seed & $7,830,000$ & 31.07 \\
Fertilizer & $3,954,750$ & 15.69 \\
Pesticides & $2,362,500$ & 9.37 \\
Bamboo canes & $1,725,000$ & 6.84 \\
Mulching sheet & $7,830,000$ & 31.07 \\
Paid labor & 452,000 & 1.79 \\
Tractor & 765,000 & 3.04 \\
Total variable cost & $24,919,250$ & 98.87 \\
\hline B. Fixed cost & & \\
Depreciation & 228,550 & 0.91 \\
Tax & 55,750 & 0.22 \\
Total fixed cost & 284,300 & 1.13 \\
\hline C. Total cost & $25,203,550$ & 100.00 \\
\hline D. Returns & & \\
Revenue & $83,554,800$ & \\
Net returns & $58,351,250$ & \\
Net returns (per ha) & $160,968,965$ & \\
R/C Ratio & 3.32 & \\
\hline Notes: 1 USD = 14,121 IDR (1 August 2019)
\end{tabular}

The average productivity per farm for one planting season was 5.968 tons (or 16.464 tons per ha). The revenue per year (for two planting season) generated by melon farmers in the study area was Rp83,554,800, which was obtained from the average production of 11.94 tons per year with the price of $\mathrm{Rp} 7,000 / \mathrm{kg}$. The net returns were Rp58,351,250 per farm per year, or Rp160,968,965 per ha per year. The revenue cost ratio was 3.32, meaning that for each $\mathrm{Rp} 1,000$ used in the production cost, there will be a revenue of $\mathrm{Rp} 3,320$. Therefore, based on the information in Table 1, it is obvious that melon farming is a profitable venture in the study village.

The monthly net returns from melon farming are higher than the provincial minimum monthly wage rate of $\mathrm{Rp2}, 351,870$ in 2019 assigned by the provincial government of Southeast Sulawesi. The $\mathrm{R} / \mathrm{C}$ ratio of 3.32 is higher than the $\mathrm{R} / \mathrm{C}$ ratio of 1.68 in Banyuwangi District [18], 1.89 in Banyuwangi 
District [19], and 3.28 in Purworejo district [20]. This $\mathrm{R} / \mathrm{C}$ ratio is also higher than that reported in Gombe and Bauchi States, Nigeria [21] and Cankiri Province, Turkey [16]. However, it is lower than the $\mathrm{R} / \mathrm{C}$ ratio of 5.42 in Central Lombok District [22].

\subsection{Economic returns of watermelon}

Table 2 showed the cost and returns of watermelon production among the respondents. The total production cost per farm was Rp14,276,425, which consisted of variable cost and fixed cost. The share of total variable cost in the total cost was 98.74 percent. The smallest variable cost was for pesticides (2.46 percent), and the highest was for mulching sheet (62.41 percent). The cost of mulching sheet was the highest among all components in the variable costs. The proportion of labor cost in the total variable cost was only 3.67 percent. This is because respondents use family labors in most of farming operations. Hired labors were used in planting and harvesting, including tractors during land preparation. Total fixed cost was Rp179,175 or 1.26 percent of the total cost. Fixed costs consisted of depreciation and tax. Depreciation consisted of depreciation for tools and equipment.

Table 2. Cost and returns of watermelon farming

\begin{tabular}{|l|r|r|}
\hline Items & Value $(\mathrm{Rp})$ & \multicolumn{1}{|c|}{$\%$} \\
\hline A. Variable cost & & \\
Seed & $1,248,000$ & 8.74 \\
Fertilizer & $2,268,500$ & 15.89 \\
Pesticides & 351,750 & 2.46 \\
Mulching sheet & $8,910,000$ & 62.41 \\
Paid labor & 524,000 & 3.67 \\
Tractor & 795,000 & 5.57 \\
Total variable cost & $14,097,250$ & 98.74 \\
\hline B. Fixed cost & & \\
Depreciation & 134,175 & 0.94 \\
Tax & 45,000 & 0.32 \\
Total fixed cost & 179,175 & 1.26 \\
\hline C. Total cost & 14.276 .425 & 100.00 \\
\hline D. Returns & & \\
Revenue & $71,400,000$ & \\
Net returns & $57,123,574$ & \\
Net returns (per ha) & $134,408,409$ & \\
R/C Ratio & \multicolumn{2}{|c|}{5.00} \\
\hline Notes: 1 USD = 14,121 IDR (1 August 2019) \\
\hline
\end{tabular}

The average productivity per farm for one planting season was 7.14 tons (or 16.8 tons per ha). The revenue per year (for two planting season) generated by watermelon farmers was Rp71,400,000 which was obtained from the average production of 14.28 tons per year with the price of $\mathrm{Rp} 5,000 / \mathrm{kg}$. The net returns from watermelon farming per year were Rp57,123,574, or Rp134,408,409 per ha per year. The monthly net returns from watermelon farming are higher than the provincial minimum monthly wage rate of $\mathrm{Rp} 2,351,870$ in 2019 assigned by the provincial government of Southeast Sulawesi. The R/C ratio of 5.00 is higher than the R/C ratio of 2.07 in Sragen District [23], and 3.31 in Sigi district [24]. This R/C ratio is also higher than that in four provinces in Iran [25], Gombe and Bauchi States, Nigeria [21] and Ladakh, India [26]. However, the ratio is lower than that of 7,43 in Central Lombok District [22].

\subsection{Differences in economic returns}

Net returns are defined as the difference between total revenue and total cost. As can be seen in Tables 1 and 2, the total revenue and net returns (both in per farm and per ha units) in melon farming were higher than that of watermelon farming.

The hypothesis of "no differences between the two means" for per farm net returns and per hectare net returns was tested using an independent sample t-test. The test result for per farm net returns is $t(28)$ $=0.152, p=0.881$. The $p$-value 0.881 is higher than 0.05 , so the null hypothesis is accepted. This result indicates that the difference between the per farm net returns from melon and watermelon production is not statistically significant. However, the test result for per hectare net returns is $t(33)=$ $16.666, p<0.001$. The $p$-value is less than 0.05 , so the null hypothesis is rejected. This result indicates that the difference between per ha net returns of melon and watermelon farming is statistically significant.

The difference in the statistical significance of per farm net returns and per hectare net returns is related to the difference in the farm size. Average farm size was 0.36 ha for melon and 0.42 ha for watermelon, whereas the net returns were almost the same. When the unit was changed from per farm to per hectare, the net returns from melon were much higher than that of watermelon with the difference

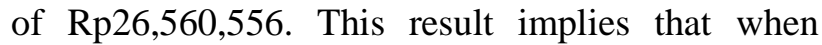
grown in the size of 1 ha and higher, melon farming is more profitable than watermelon farming.

The findings of this study revealed that both melon and watermelon farming are profitable as indicated by their Revenue-Cost Ratio being higher than 1. As mentioned previously, the status of both crops as being profitable applies not only in Indonesia but also in other countries. In Southeast Sulawesi, the net returns from either melon or watermelon farming are higher than that of other crops, such as cocoa [27], pepper [28], clove [29], patchouli [30], rice [31], key lime [32], and maize [33]. Given the small cultivated area and low production of both crops in the province, the results of this study imply the promising prospect for the 
cultivation and development of the two crops. In addition to the lack of knowledge and skills in farming practices, such small cultivated area and low production could be attributable to other several factors, such as lack of access to appropriate modern technology, the inaccessibility to credit facilities, high labor cost, and lack of other necessary social infrastructure facilities [34]. Adoption of the new crops might also be related to the level of education [35], mass media utilization, extension activities, income [36], good market price, and availability of inputs and market [37]. Therefore, the local government and all stakeholders need to address these areas of weaknesses in order to fully exploit melon and watermelon production potential.

High farm returns are most probably one of the reasons farmers shifted from growing one crop to another, which in the case of the present respondents, the shift is from rice farming to melon and watermelon production. This proposition is based on a previous study done at the same location where economic returns was identified as one of the reasons farmers have shifted from rice production to brick making $[12,17]$ and to key lime production [32]. This result also corroborates the findings reported by Yusuf et al. [37], David [38], Daulay et al. [39] and Feintrenie et al. [40] that economic returns is an essential reason for farmers or villagers to shift to new crops or livelihoods.

Weather condition, fertilizer availability, and water availability during dry season were three major issues that farmers have been facing in melon and watermelon production. The two crops are highly sensitive to excessive and erratic rain, which often occurs due to climate change [41]. Farmers reported to experience fertilizer shortages more often recently, as allocation of subsidized fertilizer to the village is based on the fertilizer needs of rice farming whereas horticultural crops require more fertilizer than rice. Water shortage was related to the damaged irrigation outlet leading to the lessfunctioning of irrigation system [17]. During the dry-season, farmers usually used gasoline-powered water pump to move water from its source to the field through a hose.

Being profitable crops with high net returns, melon and watermelon production provides many advantages to the farmers and local community, namely increasing household income, improving food and nutrition security, alleviating poverty, and promoting rural economy. Therefore, the government and stakeholders should support melon and watermelon growing by addressing issues that farmers have been facing, which might be different from one place to another. To address the issue of uncertain weather conditions in the study area, for example, the local government can provide weather forecast results regularly to the growers, so that they can better decide on the planting date and reduce the risks of possible harvest failure. Future studies need to focus on factors that determine the adoption of melon and watermelon growing and the likelihood for their adoption in other areas in the province.

\section{Conclusion}

Both smallholder melon and watermelon farming are profitable ventures as indicated by $\mathrm{R} / \mathrm{C}$ ratio being more than 1. Farmers grew melon and watermelon in small-scale, so the difference in their net returns per farm was not statistically significant. However, per hectare net returns of melon farming was statistically significantly higher than that of watermelon farming. Net returns from both crops are higher than the provincial minimum monthly wage, and than that of many other crops grown in the province. Smallholder farmers can increase their income by cultivating larger farming size. Farmers should be encouraged to continue the production of the two crops as they can improve their income and promote rural economy. The government and stakeholders can support the development of the two crops by extending weather forecast results regularly to the growers, increasing the allocation of subsidized fertilizers, and improving availability of irrigation water.

\section{Acknowledgment}

The authors would like to thank the head of Abenggi village for all his support during the field survey.

\section{References}

[1] Y.C. Huh, H.S. Choi, I. Solmaz, N. Sari, S. Kim, Morphological characterization of Korean and Turkish watermelon germplasm, Korean Journal of Agricultural Science. Vol. 41, No. 4, 2014, pp. 309-314.

[2] M.O. Abiola, I. Daniel, Efficiency of Melon Production in Oredo and Egor Local Government Area of Edo State, Nigeria, International Journal of Agriculture Innovation and Research, Vol. 2, No. 5, 2014, pp. 732-738.

[3] FAOSTAT, Web Page of the Food and Agriculture Organization of the United Nations. Statistic Database. Production statistics, 2020.

[4] H. Saediman, S. Aisa, M. Zani, M.A. Limi, W.O. Yusria, Food Security Status of 
Households in a Cassava-Growing Village in Southeast Sulawesi, Indonesia, Journal of Agricultural Extension. Vol. 23, No. 1, 2019, pp. 199-209.

[5] M. Zani, H. Saediman, S. Abdullah, L. Daud, L. Yunus, Determinants of Household Food Expenditure in a Cassava Growing Village in Southeast Sulawesi, Academic Journal of Interdisciplinary Studies. Vol. 8, No. 3, 2019, pp. 302-310.

[6] T.B. Purwantini, Saptana, S. Suharyono, Program Kawasan Rumah Pangan Lestari (KRPL) di Kabupaten Pacitan: Analisis Dampak dan Antisipasi ke Depan, Analisis Kebijakan Pertanian, Vol. 10, No. 3, 2012, pp. 239-256.

[7] K. Anwar, Hardinsyah, Konsumsi Pangan dan Gizi Serta Skor Pola Pangan Harapan pada Dewasa Usia 19-49 Tahun di Indonesia, Jurnal Gizi Dan Pangan. Vol. 9, No. 1, 2014, pp. 51-58.

[8] Kementerian Pertanian Republik Indonesia, Statistik Produksi Hortikultura 2014, Kementerian Pertanian Republik Indonesia, Jakarta, 2015.

[9] Badan Pusat Statistik, Statistik Tanaman Sayuran dan Buah-Buahan Semusim 2017, Badan Pusat Statistik, Jakarta, 2018.

[10] H. Saediman, Prioritizing commodities in southeast sulawesi province of indonesiausing AHP based borda count method, Asian Social Science, Vol 11 No. 15, 2015, pp. 171-179.

[11] BPS Sulawesi Tenggara, Sulawesi Tenggara dalam Angka 2018, BPS Sulawesi Tenggara, Kendari, 2019.

[12] H. Saediman, Mustika, L. Nalefo, M. Tufaila, M. Zani, Cost and Return Analysis of Rice Farming and Brick Making in South Konawe District of Southeast Sulawesi, International Journal of Scientific and Technology Research. Vol. 8, No. 10, 2019, pp. 835-838.

[13] H. Saediman, A. Amini, R. Basiru, L.O. Nafiu, Profitability and Value Addition in Cassava Processing in Buton District of Southeast Sulawesi Province, Indonesia, Journal of Sustainable Development. Vol. 8, No. 1, 2015, pp. 226-234.

[14] H. Saediman, S. Kurniansi, W.O. Yusria, L. Geo, Economic Returns And Production Constraints In Palm Sugar Processing In Kolaka District Of Southeast Sulawesi, International Journal of Scientific and Technology Research. Vol. 8, No. 11, 2019, pp. 3967-3970.

[15] S. Surni, H. Saediman, F. Wulandari, M. Zani, L. Yunus, S.A.A. Taridala, Profitability and constraints of small-scale tomato production in Baubau municipality of Southeast Sulawesi, WSEAS Transaction on Environment and Development. Vol. 16, 2020, pp. 219-225.

[16] H. Yilmaz, V. Demircan, S. Kurtluk, An Economic Analysis of Open-Field Melon (Cucumis Melo L.) Production in Cankiri Province of Turkey, Bulgarian Journal of Agricultural Science, Vol. 17, No. 4, 2011, pp. 484-490.

[17] L. Geo, H. Saediman, Rice farming to brick production: What are major drivers of livelihood shift?, Bioscience Research. Vol. 16, No. 4, 2019, pp. 3640-3647.

[18] A. Zubaidi, A.A. Sa'diyah, Analisis Efisiensi Usahatani Dan Pemasaran Melon Di Kecamatan Muncar Kabupaten Banyuwangi, Buana Sains. Vol. 12, No. 2, 2012, pp.19-26.

[19] B.I. Amnimarlianda, I. Syafi'i, A. Supriono, Analisis Pemasaran Dan Pendapatan Usahatani Semangka Kelompok Tani Ridho Lestari Di Desa Tembokrejo Kecamatan Muncar Kabupaten Banyuwangi, JSEP Journal of Social and Agricultural Economics. Vol. 11, No. 2, 2018, pp. 46-54.

[20] R. Andrianto, I.A. Wicaksono, D.P. Utami, Analisis Usahatani Melon Di Desa Wonosari Kecamatan Ngombol Kabupaten Purworejo, Surya Agritama. Vol. 7, No. 2, 2018, pp. 94106.

[21] Y. Adamu, A. Jongur, J. Onu, Differentials in Returns of Water Melon (Citrullus lanatus) and Sweet Melon (Cucumis melon) Production among Farmers in Gombe and Bauchi States, Nigeria, Asian Journal of Agricultural Extension, Economics and Sociology. Vol 14, No. 3, 2016, pp. 1-9.

[22] A. Mujianingsih, Analisis Pendapatan dan Penyerapan Tenaga Kerja pada Usahatani Melon dan Semangka di Kabupaten Lombok Tengah, Unpublished Thesis, Universitas Mataram, 2015.

[23] F.E.T. Astutiningsih, Analisis Pendapatan Usahatani Semangka (Citrullus vulgaris) di Kabupaten Sragen, Unpublished Thesis, Universitas Sebelas Maret, 2009.

[24] F. Juprin, Analisis pendapatan dan kelayakan usahatani semangka di Desa Maranatha Kecamatan Sigi Biromaru Kabupaten Sigi, E-J. Agrotekbis. Vol. 4, No. 3, 2016, pp. 343-349. 
[25] R. Moradi, P.R. Moghaddam, H. Mansoori, Energy use and economical analysis of seedy watermelon production for different irrigation systems in Iran, Energy Reports. Vol. 1, 2015, pp. 36-42.

[26] S. Lakdan, L. Stanzen, Economic analysis of watermelon based on production system in Trans-Himalaya region of Ladakh, Journal of Pharmacognosy and Phytochemisry. Vol. 6 No. 6, 2017, pp. 2602-2604.

[27] Jusmanto, Analisis Komparasi Produksi dan Pendapatan Usahatani Kakao pada Pola Tanam Tumpang Sari dan Monokultur di Kecamatan Watubangga Kabupaten Kolaka, Unpublished Thesis, Universitas Sembilanbelas November, 2017.

[28] K.A. Mahardika, A. Bafadal, M.A. Limi, Analisis Kontribusi Usahatani Lada Terhadap Pendapatan Petani di Desa Mowila Kecamatan Mowila Kabupaten Konawe Selatan, Jurnal Ilmiah Membangun Desa Dan Pertanian. Vol. 3, No. 4, 2018, pp. 95100.

[29] A. Asniar, Analisis Perbedaan Pendapatan Usahatani Cengkeh pada Penjualan Bentuk Basah dan Kering di Desa Pewisoa Jaya Kecamatan Tanggetada Kabupaten Kolaka, Unpublished Thesis, Universitas Sembilanbelas November, 2014.

[30] R. Wulandari, U. Rianse, W.G. Abdullah, Analisis Harga dan Keuntungan Usahatani Nilam di Desa Benua Kecamatan Benua Kabupaten Konawe Selatan, Jurnal Ilmiah Membangun Desa dan Pertanian. Vol. 3, No. 2, 2018, pp. 43-49.

[31] D. Dermawansa, T. Buana, M. Zani, Analisis Pendapatan Usahatani Padi Sawah dan Sayuran di Desa Dawi-Dawi Kecamatan Wonggeduku Kabupaten Konawe, Jurnal Ilmiah Agribisnis. Vol. 2, No. 1, 2017, pp. 13-18.

[32] I. Fausayana, Y. Miniarti, R. Rosmawaty, Perbedaan Pendapatan Peralihan Lahan Usahatani Padi Sawah Menjadi Usahatani Jeruk Nipis Di Desa Watabenua Kecamatan Landono Kabupaten Konawe Selatan, Jurnal Ilmiah Membangun Desa dan Pertanian. Vol. 4, No. 5, 2019, pp. 117-121.

[33] R.P. Sari, Dampak Penggunaan Teknologi Pertanian Terhadap Perubahan Pendapatan Masyarakat Petani Jagung di Kelurahan Wataliku Kabupaten Muna (Studi di Kelurahan Wataliku Kecamatan Kabangka Kabupaten Muna), Jurnal Penelitian Pendidikan Geografi. Vol. 3, No. 3, 2018, pp. 27-38.

[34] B.T. Mohammed, Socio-economic Analysis of Melon Production in Ifelodun Local Government Area, Kwara State., Nigeria Journal of Development and Agricultural Economics. Vol. 3, No. 8, 2011, pp. 362-367.

[35] M.G. Kerutagi, M. Talavar, A.S. Pavitra, Impact of horticulture based integrated farming system on farmer's income and welfare in Northern Karnataka, Journal of Pharmacognosy and Phytochemistry. Vol. 8, No. 3, 2019, pp. 1010-1019.

[36] B.P. Borkar, V.V. Gohad, Correlates of Knowledge and Adoption of Grain Storage Methods by the Respondents, Journal of Agricultural Research and Technology. Vol. 41, No. 2, 2016, pp. 273-276.

[37] S.F.G. Yusuf, F.S. Lategan, I.A. Ayinde, Profitability and Adoption of Watermelon Technologies by Farmers in Moro Local Government of Kwara State, Nigeria, Journal of Agricultural Science. Vol. 5, No. 3, 2013, pp. 91-99.

[38] J. Davis, Rural non-farm livelihoods in transition economies: emerging issues and policies, electronic Journal of Agricultural and Development Economics. Vol. 3, No. 2, 2006, pp. 180-224.

[39] A.R. Daulay, K.P. Eka Intan, B. Barus, N.B. Pramudya, Rice Land Conversion into Plantation Crop and Challenges on Sustainable Land Use System in the East Tanjung Jabung Regency, Procedia - Social and Behavioral Sciences, Vol. 227, 2016, pp. 174-180.

[40] L. Feintrenie, S. Schwarze, P. Levang, Are Local People Conservationists? Analysis of Transition Dynamics from Agroforests to Monoculture Plantations in Indonesia, Ecology and Society. Vol. 15, No. 4, 2010, pp. 37.

[41] H. Saediman, L.O. Lasmin, M.A. Limi, U. Rianse, L. Geo, Rice Farmers' Perception of Climate Variability in South Konawe District of Southeast Sulawesi, International Journal of Scientific and Technology Research, Vol. 9, No. 2, 2020, pp. 31283132

\section{Creative Commons Attribution License 4.0 (Attribution 4.0 International, CC BY 4.0)}

This article is published under the terms of the Creative Commons Attribution License 4.0 https://creativecommons.org/licenses/by/4.0/deed.en_US 